delivered hoped that any future birth would be in the care of their general practitioner with $11 \%$ opting for a home confinement. ${ }^{2}$ That most women would favour an increased role for their general practitioner in intrapartum obstetric care reinforces the value of general practitioners in all areas of obstetrics and the importance of recognising birth as a life event not a medical procedure.

With increasingly consumer oriented medicine the opinions and interests of pregnant mothers should be regarded even when this may mean altering the balance of current policies, particularly when there is little useful evidence to indicate which types of confinement are safer.

With appropriate encouragement the rebirth of general practitioner obstetrics is at hand. Problems may arise, however, in persuading many genera practitioners to embrace again an idea that until recently has been regarded as both outmoded and dangerous.

Walkley,

J E HOLDSWORTH

Sheffield S6 3TQ

1 Jewell D. General practitioner obstetrics. Br Med $\mathcal{F}$ 1989;298: 690-1. (18 March.)

Taylor A. Maternity services: the consumer's view. I R Coll Gen Pract 1986;36:157-60.

\section{The prone position, scoliosis, and cot death}

SIR,-Both Professor Robert A Dickson' ${ }^{1}$ and $\mathrm{Mr}$ D A Jones ${ }^{2}$ recommend that babies should be nursed prone to protect them from developing early onset scoliosis. As there is now some evidence that infants who sleep prone are at greater risk of cot death ${ }^{3}$ we need to be certain that the advice given in relation to scoliosis is well founded.

Professor Dickson and $\mathrm{Mr}$ Jones cite two pieces of evidence to support their views. Firstly, Mc Master noted a drastic fall in the number of children presenting to the Edinburgh scoliosis service with infantile idiopathic scoliosis over the years 1973 to 1982 ; he argued that this coincided with an increased tendency for mothers to nurse their babies prone and suggested "that the onset of scoliosis may be associated with immobility in the supine or lateral position." However, not all scoliosis centres have noticed this change, and in the west of Scotland the number of children with early onset scoliosis has remained constant at about eight each year since 1976, two thirds of these deformities being progressive. An explanation for these conflicting findings may be that before 1976 there was no scoliosis service in the west of Scotland and all children with progressive deformities were referred to Edinburgh. Secondly, there is the claim that early onset scoliosis is virtually unknown in North America, but this has been questioned recently by Leatherman and Dickson, who believe that there is no great difference between the United Kingdom and United States in terms of prevalence.

Thus more data are required before one can support the advice that all babies should be laid prone. Perhaps Dr J P Nicholl can say whethe early onset scoliosis is common in the Chinese ${ }^{6}$ It should be if the supine position is bad for the spine.

\section{Department of Orthopaedic Surgery,}

ALAN N CONNER

Royal Hospital for Sick Children,

Glasgow G3 8S

1 Dickson RA. Idiopathic scoliosis. Br Med f 1989;298:906-7. (8 April.)

2 Jones DA. Sudden infant death syndrome. Br Med $\mathcal{F}$ 1989;298: 959. (8 April.)

3 Milner AD, Ruggins N. Sudden infant death syndrome. Br Med f 1989;298:689-90. (18 March.)

McMaster MJ. Infantile scoliosis: can it be prevented? $\mathcal{f}$ Bone foint Surg [Br] 1983;65:612-7.

Leatherman KD, Dickson RA. The management of spinal deformities. London: Wright, 1988.
Leatherman

mities. London: Wright, 1988.
Nicholl JP. Sudden infant death syndrome. Br Med f 1989;298: 959-60. (8 April.)

\section{NHS review}

SIR, - Dr Edwin Martin sees no danger in practice budgets. He quotes 10 of his own papers showing how well he has developed services for patients under our existing contract which is set in the context of the NHS as it is at present organised. Do he and his partners really believe that the white paper's proposals will encourage other practices to follow his excellent example and does he think that his own achievements will not be undermined?

There is an initial attraction to budget holding if one believes that holding a budget will enable a practice to receive more money to develop more services and show that this is being done efficiently and effectively.

The whole experience of budgets in our cash limited hospital service is, however, to contain the care provided within a finite resource. Budgets for practices will similarly call a halt to service development in general practice. Dr Martin will then be blamed by his patients for not providing for their needs and demands. He will not be able to "cry poverty" and say that his budget is inadequate as he will be expected to balance the needs of one patient against the needs of another. I always find it difficult to play God and stand in judgment over individuals-particularly when patients seeking my advice believe that I will consider their individual cases on their merits without diminishing them because of my own interestsdeclared or otherwise.

Practice budgets will undermine the general practitioner's role as a skilled and knowledgeable advocate on behalf of patients within the National Health Service. Perhaps this is the intention. If general practitioners no longer demand on behalf of patients the services they require the government's job to fund the service will be much easier. Self satisfaction is a recipe for complacency. Our patients deserve better.

Manchester M25 7FH

SIMON JENKINS

1 Martin E. NHS review. The benefits of budgets. Br Med $\mathcal{F}$ 1989;29:889. (1 April.)

SIR, - The government has chosen to confront the profession with several issues which have long been on its shopping list, such as medical audit, shifting consultant contracts to district level, the merger of district health authorities and family practitioner committees, and reform of merit awards. But these shrink to insignificance compared with the two main thrusts of the white paper

Firstly, money will reach the hospitals only as a result of decisions made in primary care. This would be right if primary care based authorities, which would be representing their communities, made decisions about the balance between primary and secondary care spending, as in the proposals of the Medical Practitioners' Union for neighbourhood health committees. ' But general practitioners holding budgets will have a limited choice from a limited range of services, with the government deciding on the scope of the range and the size of their budgets. It will simply be an extension of NHS cuts from the hospital service to general practice with general practitioners as managers.

Secondly, centralisation is proposed. If Working for Patients is implemented district health authorities will be in the hands of government political appointees, and they will also be the dominan customers of the self governing hospitals. Small groups of the minister's appointees acting as dominant customers will ensure that the self governing hospitals, though completely free and independent, are none the less able to exist only if they do the minister's will.

What is the purpose of creating this centrally directed monopsony? If it had been produced by a government of the left it could be used to overcome the power of the professions and to reshape an expanding service. If it had been produced by a centre right or even centre left government a more technocratic approach would prevail. District health authorities would be run by reformed hackers sitting in front of large computers trading off outcome indicators against costs.

But Working for Patients comes from a government strongly influenced by the far right. Centralisation will be used to cut public spending, and district health authorities will be underfunded and will sacrifice quality to maintain quantity. Self governing hospitals will not remain public corporations for long. They will be sold. And are the district health authorities and budget holding general practitioners intended to last for ever as public buying authorities? Or are they, too, transitional phenomena to be replaced eventually by commercial companies?

The profession has been right in its united opposition to the white paper, but as well as rejecting the whole package perhaps it should also argue that it be unpacked.

STEPHEN WATKINS

Oldham OL2 8LW

STEVE ILIFFE

London NW6 6RY

1 Medical Practitioners' Union Demacratisation of the NHS - an MPU discussion document. London: MPU, 1987.

SIR, - Mr Bernie O'Brien's paper ${ }^{1}$ on indicative drug budgets for general practitioners was a useful appraisal of the government's proposals as far as they are known, but one of his conclusions has to be challenged.

He states that, though Prescribing-A Suitable Case for Treatment, ${ }^{2}$ a large study conducted in general practice, may show that receiving information feedback passively can alter some doctors' behaviour, the burden of evidencefrom hospital studies-suggests that budgetary incentives and sanctions are necessary to bring about change.

Our study was explicitly designed on the premise that passive feedback would be insufficient on its own and therefore included a series of meetings for the doctors taking part. At these meetings the doctors actively discussed the analyses we gave them and the changes they wanted to make in their prescribing. The results were a vindication of the principles of adult education and offer a way forward very different from that of the white paper.

CONRAD M HARRIS

Department of General Practice,

St James's Hospital

Leeds LS9 7TF

1 O'Brien. Indicative drug budgets for general practitioners: a prescription for change. Br Med $\mathcal{f}$ 1989;298:944-6. (8 April.)

2 Harris CM, Jarman B, Woodman E, White P, Fry JS. Prescribing - a suitable case for treatment. London: Royal College of General Practitioners, 1984

\section{Canadian health care "in crisis"}

SIR,-Minerva's assertion that American doctors are looking enviously at the Canadian health care system ${ }^{1}$ will prompt a good deal of eyebrow raising on this side of the Atlantic and on both sides of the US-Canadian border.

To cite just a few recent instances, the Canadian media have devoted much critical attention to what is described (with some justification) as a "system in crisis"; the Ontario government has recently imposed a derisory $1.75 \%$ fee increase on the province's physicians after acrimonious negotiations, during the course of which evidence of 